\title{
Irish research response to dairy quality in an era of change
}

B. O'Brien ${ }^{1 \dagger}$, T. Beresford², P.D. Cotter ${ }^{2}$, D. Gleeson ${ }^{1}$, A. Kelly³, K. Kilcawley², J. Magan², S. McParland¹, E. Murphy²,

T. O'Callaghan ${ }^{3}$, J. Tobin ${ }^{2}$ and M. Fenelon ${ }^{2}$

${ }^{1}$ Teagasc, Animal and Grassland Research and Innovation Centre, Moorepark, Fermoy, Co. Cork, Ireland

${ }^{2}$ Teagasc, Food Research Centre, Moorepark, Fermoy, Co. Cork, Ireland

${ }^{3}$ School of Food and Nutritional Sciences, University College Cork, Cork, Ireland

Abstract

The Irish dairy sector is recognised for its very significant contribution to the national economic status; it is now worth $€ 5$ billion annually and represents the largest food and drink export category, which, in turn, represents one of the four largest manufacturing industries in the country. Given anticipated further growth in global demand for dairy products and the positive attributes and capabilities that Ireland has to meet that demand, in terms of pasturebased production and cost competitiveness, it is incumbent for the sector to attain the highest quality milk and dairy products. The combined collaborative approach between research and industry has ensured significant progress and enabled Ireland to remain at the forefront globally in terms of production of quality milk and dairy products. This paper highlights some specific scientific platforms and technologies currently shaping the industry in this regard and discusses current research activity as well as anticipating key requirements for future progress. While research, and farm and processing plant management have accomplished very significant advances in milk and dairy product quality, some overarching emerging challenges include product substitution and sustainability. Some key pillars for the future have been identified on which a strong, efficient dairy sector can be maintained and progressed. Specifically, the use of evidence-based information and real-time measures in prediction and decision-making will be a crucial pillar for the dairy sector of the future. This can promote an approach of proactive maintenance and optimisation of production through improved predictability and control of manufacturing processes.

Keywords

Grass-fed milk $\bullet$ Irish dairy sector $\cdot$ milk processing $\bullet$ milk quality $\cdot$ seasonality

\section{Introduction}

Positive changes in the quality of milk have had a profound impact on the development of the Irish dairy industry over past years. The description and interpretation of milk quality in the early 1960s was very different to today's standards; at that time, only $7 \%$ of milk passed a 3-h methylene blue test, regarded as the minimum quality standard for manufacturing milk. However, from this point onwards, a strategy was initiated to improve milk quality encompassing advice at farm and creamery level and payment incentives based on quality. Further significant milestones on the journey to enhanced quality included the introduction of on-farm refrigeration, which was a key development at that time, but it was accompanied by challenges such as a requirement for consistent and adequate electrical power, which was not widespread in rural areas then. This was followed by the development of a vacuum system to transfer milk from the farm tanks to the tanker lorries of the milk purchaser; this, in turn, allowed the milk to be collected by the purchaser and transported direct to central creameries. Likewise, following the development of milking machines, which in the early years often caused mastitis spread in the herd (Walshe, 1968), a greater understanding of milking technology, development and testing of equipment specifications and design of milking parlours all had a positive impact on milk quality. From this point, increasing emphasis was also placed on breeding cows for enhanced milk production in terms of volume and fat content. While butter continued to be a key product, cheese production and milk drying capacity expanded significantly. These changes, along with an ever-growing emphasis on production of consumer products for international markets, 
resulted in the adoption of new and ever-increasing quality standards.

In more recent times, the concept and progression of milk quality has been defined and influenced by a wide range of parameters and standards that need to be achieved; these are dictated by the dairy products being produced, efficiencies of production and processing, consumer requirements and perceptions, international market requirements and regulatory agencies. While these parameters and standards are critical for the quality of the manufactured dairy product, they also have significant implications at the farm production and plant processing levels. Milk quality at farm level is mainly defined in terms of composition (fat, protein, lactose), somatic cell count (SCC), bacterial load including total bacteria count (TBC), thermoduric bacteria count and presence/ absence of chemical residues. While monetary incentives for optimum standards of these parameters benefit the farmer, most notably the $A+B-C$ system of milk payment (where $A$ is the price paid per $\mathrm{kg}$ of protein, $B$ is the price paid per $\mathrm{kg}$ of fat and $\mathrm{C}$ is a processing cost deduction), which more accurately reflects the true value of milk protein and fat (Dillon et al., 2008), improved milk composition also has positive implications for the processing plant. This has become even more critical following the changed structure of the industry following the abolition of milk quotas, which has seen a $54 \%$ increase in milk production in 2018 versus the 2007-2009 base, and a $21 \%$ increase in milk solids per cow, from $334 \mathrm{~kg}$ to $405 \mathrm{~kg}$ (Kelly et al., 2020).

So, the sector must remain vigilant; there is an anticipated growth in global demand for dairy products, but this is likely to be accompanied by ever-increasing consumer interest in animal welfare and environmental perspectives. A pre-requisite for the manufacture of quality dairy products is to start with milk of the highest quality. The definition of optimum quality milk will evolve over time, but it is a measure of success for an industry sector to be able to retain flexibility and meet changing demands and trends. This paper will highlight some scientific advances and examine some current research aspects and knowledge of milk quality that can contribute to meeting future targets in support of the Irish dairy industry.

\section{Key scientific advancements}

Animal genetics and practical implications for milk quality Ireland has been at the forefront in both research and the application of animal genetics. Genetic selection is known to contribute substantially to gains in performance traits, including milk yield and quality in dairy cows (Berry, 2018). In Ireland, prior to 2000, the Irish dairy cow breeding index was based on milk, fat and protein yield and protein concentration. This index was revised in 2001 to include calving interval (i.e. a measure of fertility) and survival, while protein concentration was removed from the index, then termed the Economic Breeding Index $(\mathrm{EBI})$. The $\mathrm{EBI}$ is routinely revised both in the number of traits considered and the weighting on each trait. The current EBI comprises 18 traits divided into 7 subindexes (Berry et al., 2022), offering breeders the choice to select sires on the basis of genetic merit for overall improved profitability, genetic merit for a particular aspect such as overall milk production or selection for a particular trait. Over the past two decades, the overall emphasis on milk production in the EBI has reduced from $72 \%$ in 2001 to $34 \%$ in 2020 , yet genetic potential and on-the-ground phenotypic performance continues to improve (Figure 1). While the concentration of fat and protein in milk is not explicitly included in the EBI, the negative weighting on milk yield, coupled with the positive weighting towards greater fat and protein yield, contributes to greater concentration of these components. The predicted transmitting ability (PTA) for milk fat and protein yield by year of first calving between the years 2010 and 2020 is shown in Figure 1. This increased genetic potential contributed to a 0.029 (s.e. $=0.002$ ) and 0.019 (s.e. $=0.002$ ) increase in phenotypic milk fat and protein percent, respectively, of first parity cows across the same time period (Figure 1). This validates results of Ring et al. (2021), who demonstrated a change in phenotypic milk yield and solids per unit change in respective estimated breeding value close to the expectation of 1 , based on a cross-sectional analysis of 526,923 Irish dairy cows born between 2012 and 2015

Milk recording, a paid service accessed by dairy farmers representing $53 \%$ of Irish dairy cows (www.icbf.com), involves harnessing Fourier transform infrared (FTIR) spectrometry to quantify the macro milk constituents of total fat, protein and lactose of individual cows at points throughout lactation. Over the past decade, the potential of FTIR to describe more about the milk sample and about the cow that produced the milk has been reported (DeMarchi et al., 2014; McParland \& Berry, 2016). The attraction of FTIR in predicting otherwise

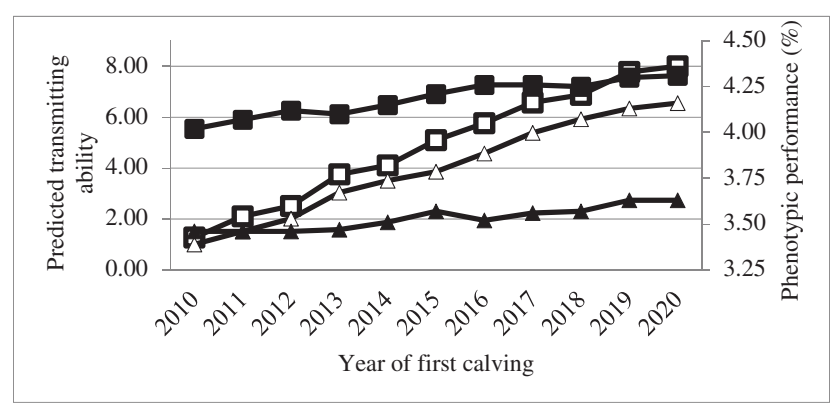

Figure 1. Genetic (white markers) and phenotypic (black markers; secondary axis) trend in milk fat (squares) and protein (triangles) yield (PTA) and composition (phenotypic) from 2010 to 2020 for first parity Irish dairy cows. 
difficult-to-measure traits arises from the routine application of FTIR to milk samples of individual cows during milk recording and to bulk tank samples at milk collection. Therefore, the pipelines already exist to capture and analyse the data, and new traits predicted from this technology can be recorded and reported at little or no additional expense or effort either to dairy farmers or to milk processors. Accuracy of the predicted traits is variable; nonetheless, some traits, including individual milk fatty acids (FAs), are predicted with very high accuracy (Soyeurt et al., 2009). Milk technological traits, including coagulation properties, heat stability, $\mathrm{pH}$ and colour, are moderately predicted, with a correlation between true and predicted values of these traits ranging from 0.30 (for milk greenness [a*]; Table 1; McDermott et al., 2016) to 0.81 (for pH; Table 1; Frizzarin et al., 2021).

Genetic gain per generation is a function of the intensity of selection, the accuracy of selection and the genetic variability. Genetic variability is one of the key determinants of genetic gain; while variability is often depicted based on the extent of the standard deviation, a more useful statistic to compare across traits is the coefficient of genetic variation, which is unit-less, thereby enabling comparison of the extent of variability across traits. Table 1 demonstrates that the coefficient of genetic variability for some FTIR-predicted milk quality traits ranges from 0.3 to 10.9 , which is within the range of genetic variation for milk yield, fat percent and protein percent estimated using the same dataset (Visentin et al., 2017). Hence, lack of genetic variation in milk quality is not a concern. The accuracy of selection is a function of the heritability of the trait and the information available from which to make selection decisions; while information used in dairy cow breeding traditionally meant phenotypic records, this is now being complemented by genomic information. The lower the heritability, the greater the number of records required to achieve a high accuracy of selection. Table 1 also summarises the heritability of a number of milk quality traits; these generally range from 0.16 to 0.46 , with the exception of milk greenness $\left(a^{*}\right)$ at 0.10 . These estimates are similar to those for milk yield and composition; hence, should these quality traits be predictable from milk samples, then a sufficiently high accuracy of selection for milk quality would be possible, equivalent to that achieved for milk yield.

As datasets increase in size and expertise in handling complex data structures improves, research continues to identify the optimal method to handle spectral data to maximise the relationship between the FTIR spectrum and novel phenotypes (Frizzarin et al., 2021). Genetic improvement of milk quality is currently a hot topic and, through the use of FTIR, access to thousands of cow lactations with regularly predicted milk quality parameters is possible. This information will assist in improving understanding of how milk quality changes across lactation, as well as quantifying relationships between milk quality and other traits of importance to the breeding goal.

\section{Molecular and bioinformatic techniques for tracking the dairy supply chain microbiome}

Central to the improvement in milk quality is the ability to rapidly identify microbes at species level across the dairy

Table 1: Accuracy of prediction of milk quality traits, including the RMSE and the correlation between true and predicted values ( $r$ ) in a validation dataset and the mean, heritability $\left(\mathrm{h}^{2}\right)$ and coefficient of genetic variation $(\mathrm{CVg})$ of FTIR-predicted traits in Irish dairy cows

\begin{tabular}{|c|c|c|c|c|c|}
\hline \multirow[b]{2}{*}{ Trait } & \multicolumn{2}{|c|}{ Prediction accuracy $^{1}$} & \multicolumn{3}{|c|}{ FTIR-predicted trait parameters ${ }^{2}$} \\
\hline & RMSE & $r$ & Mean (s.d.) & $h^{2}$ (s.e.) & $\mathrm{CVg}$ \\
\hline Milk yield (kg/day) & - & - & $20.87(6.35)$ & $0.18(-0.02)$ & 10.79 \\
\hline Protein (\%) & - & - & $3.71(0.39)$ & $0.46(-0.02)$ & 4.58 \\
\hline Fat (\%) & - & - & $4.6(1.07)$ & $0.29(-0.01)$ & 7.83 \\
\hline $\mathrm{RCT}(\min )$ & 6.40 & 0.71 & $20.37(6.22)$ & $0.28(-0.01)$ & 8.10 \\
\hline Heat stability (min) & 5.46 & 0.67 & $6.79(4.4)$ & $0.16(-0.01)$ & 10.90 \\
\hline $\mathrm{pH}$ (units) & 0.06 & 0.81 & $6.69(0.08)$ & $0.27(-0.01)$ & 0.30 \\
\hline Lightness $\left(L^{*}\right)$ & 1.57 & 0.55 & $81.63\left(\mathrm{NA}^{3}\right)$ & $0.29(0.02)$ & 0.37 \\
\hline Greenness $\left(a^{*}\right)$ & 0.52 & 0.30 & $-4.05(\mathrm{NA})$ & $0.10(0.01)$ & 1.73 \\
\hline Yellowness $\left(b^{*}\right)$ & 2.03 & 0.72 & 8.23 (NA) & $0.35(0.01)$ & 1.46 \\
\hline
\end{tabular}

$\mathrm{RCT}$ = rennet coagulation time; RMSE = root mean square error.

${ }^{1}$ Prediction accuracy of RCT, heat stability and pH obtained from Frizzarin et al. (2021). Prediction accuracy of lightness, greenness and yellowness obtained from McDermott et al. (2016).

${ }^{2}$ Population parameters for milk yield, protein \%, fat \%, RCT, heat stability and pH obtained from Visentin et al. (2017). Population parameters for lightness, greenness and yellowness obtained from Scarso et al. (2017).

${ }^{3}$ Not available. 
supply chain, from farm to finished product. Conceptualising ways of combining tracking, identification and enumeration of microbes and microbial populations (microbiota) into one methodology is now possible due to advances in molecular and digital technologies. Targeted molecular approaches, such as polymerase chain reaction (PCR) and, especially quantitative (qPCR) methods of analysis are generally more sensitive, user-friendly, easier to automate and time-efficient for analysis of specific pathogens and spoilage microorganisms. Highthroughput DNA sequencing has become critically important for deeper analysis of specific strains or broader analyses of the microbiota of the dairy supply chain. Ireland is at the forefront in this research, as evidenced by the establishment of the Irish Next Generation Sequencing (NGS) Centre at the Teagasc Food Research Centre, Moorepark in 2009. This facility is the largest of its kind in Ireland and currently contains a range of DNA sequencing platforms including lon PGM, Ion Proton, Illumina MiSeq, Illumina NextSeq and the Oxford Nanopore Minlon and GridION platforms. This allows the provision of complete genomic (i.e. specific strains) and metagenomic (i.e. the genomes from the multitude of microorganisms present among a specific microbiota) analysis relevant to food manufacturing and human/animal health.

These sequencing platforms have been used in a variety of ways to study the microbiome of the dairy supply chain. One early study examined the bacterial populations in Irish artisanal cheese and revealed the presence of a number of bacteria that had not previously been associated with cheese including Faecalibacterium, Prevotella, Helcococcus, Arthrobacter and Brachybacterium (Quigley et al., 2012). This study also confirmed a number of previously observed patterns, including the dominance of typical starter and non-starter lactic acid bacteria (NSLAB) in the cheese, the increasing dominance of NSLAB as the cheese ripens and significant differences in the microbial populations of raw and pasteurised milk cheeses, all of which increased confidence that this technology could be used to study microbial populations in cheese and dairy systems. Similarly, this technology has been applied to monitor the microbiome of raw and pasteurised milk (Quigley et al., 2013) and to assist in the confirmation of Thermus thermophilus as the causative agent of the "pinking" colour defect in cheeses (Quigley et al., 2016). A recent example relates to the use of molecular and bioinformatic techniques in the dairy sector as reported by McHugh et al. (2020). The study used both 16S rRNA gene amplicon sequencing (an approach that provides information about the proportions of different bacteria present in a sample) and shotgun metagenomic sequencing (which provides information about all types of microorganisms in a population and the genes that they encode) to track changes in the microbiota of fresh, mid- or late-lactation milks from on-farm bulk tanks, collection tankers, milk silos, skim/cream silos and finished skim milk powder (SMP) samples. This high-throughput DNA sequencing analysis was complemented by bioinformatics infrastructure and expertise to allow interpretation of the data. The data obtained confirmed the complexity of the microbiota in raw milks from farm bulk tanks and collection tankers and highlighted the presence of species of Pseudomonas and Acinetobacter, potential spoilage bacteria that grow at the low storage temperatures used for milk on-farm and during transport. During storage of the milk in silos prior to processing, Pseudomonas fluorescens and Acinetobacter baumannii grew to become the dominant population. Upon processing to SMP, the population continued to reflect that of the raw milk for latelactation milks, while Thermus and Geobacillus dominated in powders made from mid-lactation milk.

The studies demonstrate the potential for integration of this technology across the dairy supply chain and the implication for quality and safety is immense. Expectations are high, as development of DNA sequencing platforms has rapidly evolved over recent years, driven by advances in molecular biochemistry, leading to, for example, handheld sequencing devices. These advances, combined with automated DNA extraction approaches and high-end computing, have revolutionised this science, providing several opportunities to place Ireland's dairy sector at the forefront of advanced analytics with a possible market advantage. When coupled with bioinformatics, these new technologies have the potential to deliver traceability, safety and provenance within today's complex dairy supply chain. It is expected that this will provide the dairy sector with powerful datasets from on-farm and factory microbiota, and information on environmental factors that influence the microbiome of dairy products. International standards are currently based on traditional microbiological agar-plate methods and there is a need to validate the use of new techniques in dairy product manufacturing processes in situ. Traceability, for instance, is key in the case of sensitive consumer markets such as in the infant formula sector, which is a prominent utiliser of Ireland's dairy ingredients. Teagasc researchers are currently working on establishing methodologies that are sufficiently robust to work in dairy ingredient processing environments, where, for example, sequential heating steps are used that will significantly impact the microbiome. However, limitations of molecular methods include the ability to enumerate viable bacterial cells, after such heating regimes. Teagasc has an active programme of work with the objective of determining viable cell recovery throughout different dairy processes. The research has the potential to provide a foundation for development of new quality control protocols and release criteria for the dairy sector to protect existing, and develop new, markets for the future. In addition, these molecular techniques can provide additional safety information for products (including raw milk products) and for countries with developing infrastructures 
and/or climates not conducive to effective control of microbial growth.

\section{Characteristics and challenges of the Irish dairy sector and research activities to address them}

\section{Seasonality of milk production in Ireland}

A seasonal milk supply is a fundamental characteristic of milk production in Ireland, with implications for milk quality, processing characteristics and price. Primary milk production in Ireland is driven by the use of pasture as a natural lowcost feed source, which has led to the widespread adoption of a seasonal calving pattern, synchronised to maximise pasture utilisation, with the majority of cows calving in early spring and a dry period of 8-10 wk during winter. This grassbased production system maximises cost efficiency and sustainability; however, the seasonal milk supply creates a volume and quality/functionality constraint for milk processors, particularly during the early- and late-lactation periods. Seasonality of milk is defined as changes in milk composition and functionality linked to the stage of lactation, that is, time post-partum, coupled with dietary changes throughout the season, which affects the suitability of milk for production of dairy products.

Fat, protein and lactose are the major macro components of milk, which are subject to variation in quantity and, in some respects, quality over the season. A study by O'Callaghan et al. (2016a) determined a significant increase in milk fat and protein contents and a significant decrease in milk lactose content in late-lactation milk derived from a grass-based, spring-calving herd. A recent study by Parmar et al. (2020) examined the effect of seasonal variation on milk composition and density in spring-calving Jersey and Holstein/Friesian cows, highlighting the importance of milk density in milk volume-weight calculations throughout the season. Milk fat content was significantly lower during summer $(4.71 \%)$, in comparison to spring (5.00\%) and autumn (5.13\%), while milk lactose content was significantly higher in autumn $(4.68 \%)$ than in spring $(4.59 \%)$ and summer $(4.62 \%)$. Milk density also varied significantly throughout the year, with the lowest average value observed during the spring months $\left(1.0304 \mathrm{~g} / \mathrm{cm}^{3}\right)$, which was significantly lower than in autumn $\left(1.0309 \mathrm{~g} / \mathrm{cm}^{3}\right)$, which was, in turn, significantly lower than in summer $\left(1.0314 \mathrm{~g} / \mathrm{cm}^{3}\right)$, primarily due to the substantially lower milk fat content during the summer months. This is critical for milk processors, as milk volume at collection is converted to mass using a density conversion factor, which, in industrial practice, currently remains constant throughout the season. Thus, the compositional variation that occurs throughout the season is not accurately reflected in estimates of milk volume-mass ratios using the standard density value, which could instead be adjusted periodically to improve accuracy.

Many studies have reported poor processing characteristics of late-lactation milk and associated quality parameters of products manufactured from that milk (Auldist et al., 1996; O'Brien et al., 2006; Downey \& Doyle, 2007). Late-lactation milk has shown poor rennet coagulability, impaired curd syneresis, high moisture content in Cheddar cheese and lower recovery of total milk fat in the cheese (Auldist et al., 1996). Maintenance of good nutritional status in spring-calved herds as they transition into late lactation (278 days in lactation) has been found to maintain better milk processing quality (heat stability, free FA levels, alcohol stability and rennet coagulation properties), as lactose, protein and casein contents were maintained at $>4.3 \%(\mathrm{w} / \mathrm{w}), 3.6 \%(\mathrm{w} / \mathrm{w})$ and $2.8 \%(\mathrm{w} / \mathrm{w})$, respectively (Guinee et al., 2007; Guinee \& O'Brien, 2010). O'Connell et al. (2016) investigated the effects of storage temperature and duration on microbial quality of bulk tank milk in mid and late lactation, and showed that proteolytic bacterial count was greater in milk in the latter stages of lactation.

A recent study by Lin et al. (2017) examined seasonal changes in the compositional, physicochemical and processing characteristics of skim milk from a mixed herd with varying proportions of milk from spring- and autumn-calving cows. These authors reported that season significantly affected concentrations of total phosphorus $(P)$ and serum $P$, levels of $\alpha_{s 1}$-and $\beta$-caseins (as proportions of total casein), casein micelle size, zeta potential and ethanol stability at different $\mathrm{pH}$ values. While season did not influence the rennet gelation or heat stability characteristics of the milk, ethanol stability of autumn/winter milk was lower than that of spring/summer milk. The absence of significant seasonal effects on many of the compositional parameters, rennet gelation and heat stability characteristics suggests that milk from a mixed herd of spring- and autumn-calving cows is more suitable (than that from spring-calving cows only) for the manufacture of cheese and milk powder on a year-round basis. Thus, where milk is predominantly derived from a pasture-based, spring-calving system, as in Ireland, the use of autumn-calving herds at critical times of the year could help to reduce the processing problems frequently encountered at the extremes of lactation. While Ireland's seasonal milk production profile facilitates cost advantages in milk production at farm level, it can involve extra costs in the processing sector, such as elevated plant capacity during the peak supply period, with under-utilisation of plant capacity in early/late lactation. This is often coupled with a seasonal labour requirement and higher fixed costs. From a national perspective, the seasonality trade-offs can be complex and evolving strategies are very much influenced by international dairy markets. A seasonal milk supply will always have a focus on bulk commodities during peak supply; however, the Irish dairy sector has engaged in innovative investments 
and has the capability of delivering a range of value-added ingredients while seasonality remains the dominant feature of Irish milk production. The driver of seasonality, that is, a grass-based/grass-fed milk production system, also creates a unique selling point for sustainable Irish dairy produce in international markets and has the potential to generate a financial return for all stakeholders within the sector.

\section{Grass-fed milk}

In recent years, there has been an increased prevalence of grass-fed dairy products on the market, driven by consumer demand associated with a perception of a more natural, environmentally sustainable production system providing improved animal welfare and better nutritional attributes. This has resulted in grass-fed dairy products achieving a premium price over more conventional non-grass-fed dairy products in some geographical markets, and has also resulted in Irish milk producers achieving a greater price in some countries. Significant research has been undertaken to examine, identify and characterise the unique compositional and sensory attributes of grass-fed dairy products, highlighting the fact that such consumer perceptions appear to have some basis in fact.

Grass-fed dairy systems are best suited to regions with a temperate climate, plentiful rainfall and fertile soils that can enable cows to be maintained outdoors grazing pasture for the majority of their lactation, whereby calving periods are synchronised for milk production to coincide with the grass growing periods of the year, that is, spring-calving dairy herds. However, this seasonal approach to milk production poses challenges to dairy manufacturers, due to synchronised changes in milk composition and quality as the herd transitions through early, mid and late stages of lactation (see review by Timlin et al., 2021). The definition of grass-fed, as such, can vary from region to region, often differing in the levels of fresh pasture in the diet, the type of grass or portion of required access to outdoor paddocks per day or per lactation. In that regard, not all grass-fed dairy products are the same, and for that reason, it is vital for regions to have clear, defined and accredited grass-fed standards (Moscovici Joubran et al., 2021).

Pasture feeding has a significant effect on the composition and quality of milk and dairy products (Alothman et al., 2019; Magan et al., 2021), with one of the greatest impacts affecting the fat fraction of the milk. A positive correlation between the proportion of fresh grass in the cow diet and levels of conjugated linoleic acid (CLA) and omega 3 FAs in the milk is well established (Kelly et al., 1998; Couvreur et al., 2006; O'Callaghan et al., 2016a). O'Callaghan et al. (2016b) found that non-grass diets (total mixed ration) produced milk with high solid content and yields and also higher levels of palmitic acid and omega 6 FAs. Grass-fed diets enhance levels of carotenoids such as $\beta$-carotene and lutein, which are natural antioxidants and precursors for vitamin A synthesis, in milk (Kalač, 2011).

The sensory characteristics of milk have also shown to be influenced by diet (Faulkner et al., 2018; Clarke et al., 2019). $\beta$-Carotene content has been shown to significantly influence the colour of dairy products and can also influence consumer perception (Faulkner et al., 2018). Multiple studies have identified differences in volatile compounds due to cows' diet and some of these have the potential to influence sensory characteristics, while others may be used to authenticate grass-fed milk and dairy products in the future (Kilcawley et al., 2018). The volatile compound $\rho$-cresol, which is particularly odour-active and has a barnyard-like aroma, is more prevalent in grass-fed dairy products, as it is a product of rumen metabolism of $\beta$-carotene and isoflavones in clover (Faulkner et al., 2018; Kilcawley et al., 2018; Clarke et al., 2019). This barnyard-like aroma appears to be more easily percieved by US (compared to Irish) consumers, persumbly due to lack of US familarity with grass-fed milk and dairy products (Kilcawley et al., 2018).

Changes in milk composition due to cow diet were shown to impact products derived from that milk. Grass-fed butter has a characteristic golden or yellow colour due to significantly higher levels of $\beta$-carotene naturally present in fresh grass (O'Callaghan et al., 2016a). Alterations to the FA profiles were shown to significantly affect the texture of butter (Couvreur et al., 2006; O'Callaghan et al., 2016b) with softer butter being produced from grass-fed than nongrass-fed milk. The impact of feed systems on the sensory perception of butter was studied by Garvey et al. (2020), who found that there was no significant difference in overall preference between grass-fed and non-grass-fed butters among US, German and Irish consumers, but cross-cultural preferences were evident and likely influenced by familiarity with grass-fed or non-grass-fed butters. The impact of pasture feeding on water-soluble vitamins (Magan et al., 2020) and metabolites (Magan et al., 2019) in SMP indicated that vitamin B3 and B3-amide concentrations were higher in total mixed ration derived samples, while vitamin B1, B2 and $\mathrm{B} 7$ concentrations were significantly higher in grass-fed derived samples. Cheng et al. (2020) found that cow diet impacted the sensory perception of SMP and that perception differed between Chinese, Irish and US consumers. The impact of diet on the sensory characteristics of cheese is less clear, mainly due to the fact that significant biochemical changes occur during cheese production and ripening that likely supersede pre-existing dietary-derived differences in the milk (O'Callaghan et al., 2017; Panthi et al., 2019). The impact of terpenes present in wild mountain pasture may, however, impact the sensory character of some regional cheeses (Kilcawley et al., 2018). 
There is a need for legislation to distinguish and protect grassfed milk products, but in order to achieve this, methods are required to authenticate grass-fed milk and dairy products. These methods are likely to be based on the unique characteristics associated with grass-fed milk, such as FA profiling, quantification of specific carotenoids, volatiles or vitamins; however, rapid spectral approaches would be of most benefit due to their low cost, robust and practical nature (Capuano et al., 2014a, 2014b; O'Callaghan et al., 2018; Gómez-Mascaraque et al., 2020; Magan et al., 2021).

\section{Somatic cell count}

In dairy cows, the initial stage of mastitis infection is subclinical, with inflammation so slight that it is not detectable by visual examination. However, at this stage of the infection, somatic cells transfer from the blood to the milk in an effort to prevent or reduce the inflammation/infection. There can be a rapid increase in milk SCC during this time, with udder quarters potentially having an SCC of $200-5,000 \times 10^{3}$ cells $/ \mathrm{mL}$. In the absence of detection, this milk becomes part of the bulk manufacturing milk, and the high SCC can negatively impact the quality and suitability of the milk for processing.

Much research has been undertaken on farm management factors influencing bulk herd milk SCC, both in Ireland and internationally. A study conducted by Kelly et al. (2009) on Irish dairy herds showed that management practices associated with maintaining low SCC included the use of dry cow therapy, participation in a milk recording scheme and the use of teat disinfection post-milking. An association between low SCC and an increased level of hygiene and frequency of cleaning of the holding yard, passageways and cubicles was also observed. In Ireland, as per European Union (EU) regulations, the SCC threshold for milk purchasers is $400 \times 10^{3}$ cells $/ \mathrm{mL}$. However, much research has indicated negative impacts of SCC below this threshold on milk processing quality, and therefore, it is clear that for production of quality dairy products, more stringent SCC levels need to be achieved.

The influence of SCC on the composition of milk and its processability into dairy products, particularly cheese, has been studied extensively; increasing SCC in milk is associated with marked changes in the concentrations of milk constituents, the state (degree of hydrolysis) of the milk components and cheesemaking properties (Politis \& Ng-KwaiHang, 1988a, 1988b, 1988c). An increase in SCC in the range of $100 \times 10^{3}$ to $1000 \times 10^{3}$ cells $/ \mathrm{mL}$ has generally been found to reduce lactose, fat and casein contents in milk, casein as a percentage of true protein, gel firmness, recoveries of protein from milk to cheese and cheese yield, and to increase cheese moisture and rates of primary and secondary proteolysis during maturation. Authors generally agree that high milk SCC is accompanied by a detrimental effect on the organoleptic properties of cheese (Barbano et al., 1991). More recent work by Geary et al. (2013a) also showed a significant negative relationship between SCC and recoveries of protein and fat; as SCC increased, cheese protein content declined and cheese moisture content increased. The impact of these compositional changes as a result of elevated SCC potentially could have significant impact on product sales, processing costs and milk returns across the dairy industry.

Mastitis is a costly disease within the dairy industry, which manifests itself at both farm and processor levels and has been identified as one of the most economically relevant diseases of dairy cattle in Ireland (More et al., 2010). Geary et al. (2012) found that Irish farms sustained large losses in profit when bulk milk SCC increased above $100 \times 10^{3}$ cells $/ \mathrm{mL}$. Furthermore, a study by Geary et al. (2013b), in which the farm and processor costs were combined, showed that, if the cell count was reduced by $10 \%$ on a national basis, this would be worth $€ 37.6$ million for the Irish dairy industry, at that time. Consequently, a concerted effort has been undertaken to reduce SCC which included the introduction of payment structures to incentivise for lower SCC milk. Payment systems, either in the form of a penalty or bonus or both, are effective tools to encourage reductions in milk SCC (Berry et al., 2006). This strategy was introduced in Ireland with the principle being that maintaining the farm bulk milk SCC below $400 \times 10^{3}$ cells $/ \mathrm{mL}$ was not sufficient, while highlighting that a bulk milk SCC $<100 \times 10^{3}$ cells $/ \mathrm{mL}$ was optimal.

The other significant approach used to reduce national milk SCC was the development of the CellCheck programme in 2010. CellCheck is the national mastitis control programme in Ireland which is coordinated and facilitated by Animal Health Ireland (https://animalhealthireland.ie/). This programme provides the knowledge to reduce SCC on farm, while also raising awareness of the costs of mastitis at farm level. Tools have been developed internationally to assist the farmer awareness/education process, for example, the Dutch cost of mastitis tool (Huijps et al., 2008). A similar decision support tool was developed for Ireland (CostCheck) using the analysis carried out by Geary et al. (2012). CellCheck has played a critical role in facilitating the collaboration of farmers, processors, service providers and government, and partnerships at farm level, co-operative and farm advisors, milking machine technicians and vets, all with the goal of improving mastitis control and milk quality on a national basis. A study by O'Connell et al. (2015) initiated the collection of bulk tank SCC data directly from each of the milk processors. These data are now collated by the Department of Agriculture, Food and Marine (DAFM) and are analysed by Animal Health Ireland every 4 mo. This dataset accounts for over $95 \%$ of the milk supplied in Ireland and is invaluable in monitoring the udder health of the national herd. Figure 2 outlines the annual average SCC from 2007 to 2020. It is clear that significant reduction in SCC was achieved over the period 2007-2017 


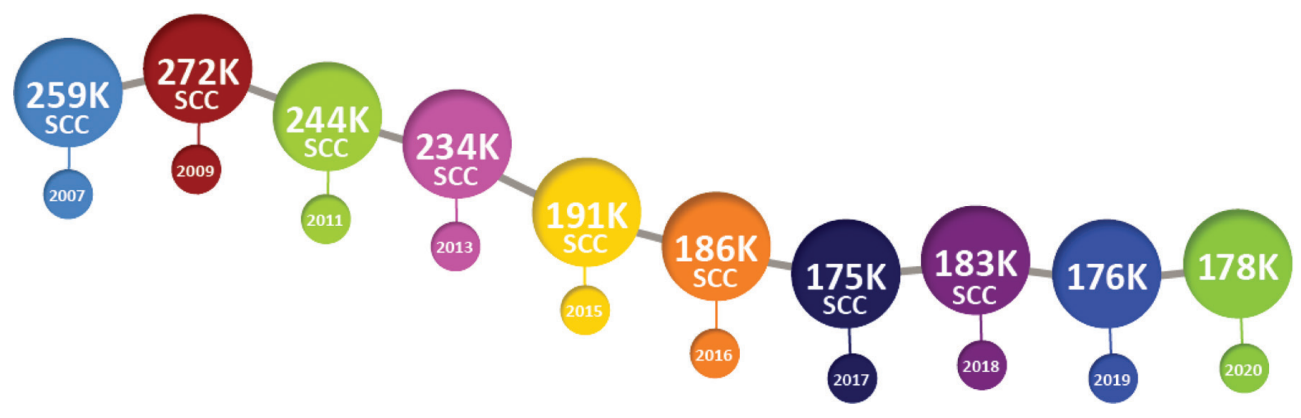

Figure 2. Annual average SCC (2007-2020).

and reduced levels were maintained thereafter, at annual SCC $<185,000$ cells $/ \mathrm{mL}$.

Continued SCC data collection and analysis is essential for measuring industry progress and change. This is an important learning for the industry, particularly as it enters a period of significant change in relation to antimicrobial use (further discussed in the paper of Mee et al. (2022) in this journal edition).

\section{Milk enzymology}

Milk has long been known to contain a diverse and complex set of indigenous enzymes from sources such as mammary epithelial cells, lysosomes of somatic cells, blood and the milk fat globule membrane. These enzymes are of significance for milk and dairy product quality from a number of perspectives, such as influence on quality (plasmin, lipoprotein lipase), use as indicators of severity of processing (alkaline phosphatase) and antimicrobial function (lactoperoxidase). For many enzymes, milk contains a complex mixture of zymogens, activators, inhibitors and substrates, some of which appear to be inactive in milk and are of unknown function (for overviews, see Fox \& Kelly, 2006a, 2006b; Fox et al., 2006; Kelly \& Larsen, 2021). Levels of enzyme activity in milk are variable and affected by factors such as stage of lactation and mastitis; for this reason, some enzymes have been proposed as potential diagnostic indicators of diseases, such as $\beta-\mathrm{N}$ acetyl-glucosaminidase (NAGase).

In addition to indigenous enzymes originating from the cow, raw milk is increasingly recognised (as a consequence of high-throughput sequencing tools) as containing a wide range of psychrotrophic bacterial species, especially of the genus Pseudomonas (Machado et al., 2017; Zhang et al., 2019). Many strains of such bacteria, if they grow to significant numbers, secrete extremely thermostable proteases and lipases. These are sufficiently thermally stable to withstand ultra-high temperature (UHT) processing (at $138-142^{\circ} \mathrm{C}$ for 2-4 s), and can result in physical instability during long-term storage; this is assisted by their ability to coagulate casein very slowly by a chymosin-like action, due to a relatively similar specificity against $\kappa$-casein, leading to a gel forming in the package (Zhang et al., 2018).

While there have been many studies on the impact of such bacterial enzymes on UHT milk quality, there have been far fewer on other dairy products, such as cheese. Recent studies between Teagasc, Moorepark and University College Cork (UCC) attempted to bridge this gap and evaluated the impact of an extracellular protease of $P$. fluorescens on rennet coagulation properties of milk and quality of Cheddar cheese. Interestingly, it was found that the protease could actually enhance rennet coagulation properties, presumably due to a synergistic action with chymosin, but that more extensive proteolytic action resulted in formation of weak gels; the impact on Cheddar cheese during ripening was relatively minor, perhaps again due to a similar action to that of chymosin (Paludetti, 2020a, 2020b). Overall, there are significant knowledge gaps that remain about the microbiology of Irish manufacturing milk in specific relation to the production of such enzymes and their persistence and role in product quality.

Another aspect of milk enzymology that has been of recent focus concerns the partitioning of enzymes during production of next-generation milk protein ingredients. For example, the indigenous milk protease plasmin is found in milk as part of a complex system that includes the inactive zymogen plasminogen, plasminogen activators (PA) and inhibitors of both plasmin and PA. Heat treatment can inactivate the inhibitors, effectively upregulating plasmin action, while membrane filtration can fractionate the enzyme and its casein substrate (as plasmin naturally associates with the casein micelles) away from the inhibitors, which are lost in the permeate (Gazi et al., 2014). The implications of such processing considerations for the ultimate stability of casein in ingredients such as micellar casein concentrate (MCC) when later incorporated into formulated food or beverage products is the subject of ongoing research at UCC (France et al., 2021). In addition, collaborative studies between UCC and Teagasc are evaluating the role of such enzymes in the ripening of cheese made from such ingredients (Li et al., 2020). 
Overall, the enzymology of milk remains an active area of research, and research teams in Ireland remain at the forefront of international study in this area; this is also reflected by the publication of a major new reference work in this field (Kelly \& Larsen, 2021).

\section{Residues}

The significance of residues in global food production, international trade and consumer confidence is gaining momentum, as evidenced by increasingly complex legal and regulatory guidelines surrounding their presence and subsequent consumption in food. Vulnerable consumers such as the very young, old or those with compromised health status can potentially be at higher risk due to the presence of these compounds in dairy foods. A factsheet developed by The Food Safety Authority of Ireland (FSAI) for foods of animal origin advises on legislation at both national and EU levels, and on monitoring/analysis of residues (FSAI, 2015). Irish and international studies of residues in milk have included organic acids, quaternary ammonium compounds and iodine. This is supported by the achievement of high sensitivity in the detection methods applied to milk, such as high-resolution mass spectrometry, which can detect a wide range of residues in milk at very low limits of quantification. In recent years, research at Teagasc has focused on residues associated with the use of chlorine-based sanitisers and the entry, partition and fate of their disinfection by-products in milk/ dairy products and strategies for their mitigation. Cleaning and disinfection are critical aspects of good manufacturing practice within the dairy sector and are essential to ensure bacteriological quality of milk and subsequent dairy products through effective sanitation of contact surfaces. However, disinfection by-products formed by the reaction of chlorine with organic/inorganic compounds during dairy processing and their potential for accumulation within finished dairy products such as butter and milk powders (often used as ingredients in infant milk formula) has led to trichloromethane (TCM) and chlorate emerging as residues of significant concern.

Contact of chlorine with organic material, for example, milk, can result in the formation of organic chlorine disinfection byproducts (Tiefel \& Guthy, 1997), consisting of volatile and nonvolatile organic chlorine. The most important of the volatile organic chlorine group is $\mathrm{TCM}\left(\mathrm{CHCl}_{3}\right)$, which has an affinity for the fat fraction in milk and hence is preferentially enriched in high-fat derivatives such as cream and butter. Germany is currently one of the most important export markets for Irish butter, and German standards surrounding TCM levels in food govern specification compliance of countries exporting therein. Thus, target TCM levels of $<0.002 \mathrm{mg} / \mathrm{kg}$ for milk and $<0.03 \mathrm{mg} / \mathrm{kg}$ for butter were recommended to meet market requirements. The main factors influencing milk TCM levels were identified by O'Brien (2009) and included having sufficient rinse water volume, not reusing rinse water, and having adequate plant drainage after wash cycles, limited reuse of detergent solutions and adherence to recommended chemical usage rates. Many of these factors were addressed in the study of Ryan et al. (2013) who demonstrated the importance of adequate rinsing of both organic (milk) and detergent residues from the milking plant; these authors recommended a minimum rinse water volume of $14 \mathrm{~L}$ water per milking unit to meet TCM targets. Implementation of improved control strategies at farm and processor level surrounding chlorine use ensured that initial TCM target levels were met. TCM target levels were subsequently reduced from 0.002 to $0.00155 \mathrm{mg} / \mathrm{kg}$ to the current level of $0.00124 \mathrm{mg} /$ $\mathrm{kg}$ in milk, with a corresponding target of $0.0124 \mathrm{mg} / \mathrm{kg}$ in butter. Routine monitoring of milk supplies in Ireland indicates that currently this target is consistently surpassed (personal communication).

Chlorate $\left(\mathrm{ClO}_{3}\right)$ residue has become a growing concern within the dairy, food and beverage industries in recent years. In addition to organic by-products like TCM, disinfection with chlorine is also associated with inorganic chlorine species, formed through oxidation reactions. Chlorine can form an extensive number of oxidised inorganic disinfection byproducts, with chlorate formation being primarily associated with the decomposition of chlorine dioxide and hypochlorite solutions (Adam et al., 1992; WHO, 2005; Snyder et al., 2009). A maximum residue level (MRL) of $0.01 \mathrm{mg} / \mathrm{kg}$ for chlorate was applied to all foods according to EU Regulation 396/2005 (EC, 2005). However, EU surveys have identified chlorate residue levels in food products, including milk and milk-based products, greater than the MRL of $0.01 \mathrm{mg} / \mathrm{kg}$ (EC, 2005). From a food safety perspective, chlorate and other oxychlorine species have been associated with the inhibition of iodine uptake in humans and the formation of methaemoglobin, with infants and young children identified as a high-risk demographic. Thus, to ensure compliance with the EU MRLs with respect to chlorate levels in Irish dairy products, a critical evaluation of cleaning and disinfection procedures applied at farms and processor level was undertaken to assess the impact of chlorine-containing disinfectants on chlorate levels and to assess potential mitigation solutions.

The presence of chlorate in milk and dairy products arises primarily from the use of chlorinated water and chlorinated detergents for cleaning and sanitation of equipment at both farm and dairy processor levels (McCarthy et al., 2018). At both farm and processing levels, degradation of hypochlorite and formation of chlorate occurs during storage of concentrated hypochlorite solutions and is dependent on concentration, product storage temperature and $\mathrm{pH}$. Thus, entry of chlorate into the dairy production chain through 
cleaning/disinfection practices will depend on the level of chlorate formed in the stored hypochlorite solution and on the efficiency of removal of chlorate residues during the rinsing cycles after disinfection (Gleeson \& O'Brien, 2016). While total removal of chlorine detergents at farm level solves the chlorate problem, this strategy could have negative implications for the microbiological quality of milk. Gleeson et al. (2013) demonstrated that chlorine-free cleaning was effective when examined over a 3-mo period, during which detergent usage rates, water temperature and rinsing protocols were closely monitored. New cleaning protocols were subsequently developed together with guidelines on the key steps required for cleaning milking equipment in a chlorine-free environment (Gleeson, 2018); this allowed an initial transition to chlorine-free cleaning on-farm without creating microbiological challenges. A further study by Yap \& Cotter (2020) examined the microbiological and residue quality of milk from farms that had adopted chlorine-free cleaning and those that continued to use chlorine-based cleaning. Improved microbial quality of milk and reduced residue levels were evident on farms using chlorine-free cleaning methods.

Disinfection of water with hypochlorite and chlorine dioxidebased solutions has also been identified as an entry route for chlorate within the dairy process. A study by Paludetti et al. (2019) highlighted that within the production process in a processing plant, chlorate levels could increase 50 -fold, due to the concentration of milk to product but also due to chlorinated rinse water. Potable water for in-process use, treated with hypochlorite or chlorine dioxide, often generates high chlorate levels therein. During equipment stabilisation, flushing and product pushout scenarios, there is high potential for comixing of water and product, risking enrichment of chlorate in finished dairy products. Alternatively, water treatment using chlorine gas does not contribute to chlorate levels in treated water (Nieminski et al., 1993). The dairy industry is now moving away from chlorine dioxide and hypochlorite solutions for water treatment, with widespread adoption of chlorine gas treatment now limiting potential cross-contamination of chlorate from water to product.

Today, partly based on the research at Teagasc, Ireland has instated a resolution to remove all chlorine-based detergents from both farms and processing plants from January 2021. This involves removing all chlorine-based products from cleaning protocols on the farm and in the processing plant and replacing them with alternative sanitisation approaches based on combinations of peracetic acid and hydrogen peroxide. While this approach broadly addresses the risk of chlorine disinfection by-products entering the dairy supply chain, vigilance surrounding emergence of other sanitation residues is essential to maintain the high safety standards to which Irish dairy products are held.

\section{Processing technology and implications for milk and dairy product quality}

The Irish dairy industry produces a range of commodities and high value dairy derivatives through a core platform of dairy technologies designed and optimised to produce the long shelf-life export products that define the Irish dairy processing sector as a whole. Key technology platforms include heat treatment, fermentation, mechanical, enzymatic, charge and size-based separations, evaporative concentration and spray-drying. The legal requirement for pasteurisation is normally met by high temperature, short time (HTST) heat treatment, which is widely used in liquid milk production using conventional plate heat-exchangers. Currently, commercial HTST pasteurisation usually refers to a heat treatment ranging from $72^{\circ} \mathrm{C}$ to $75^{\circ} \mathrm{C}$ for $15-20 \mathrm{~s}$ (Reich et al., 2017). However, meeting microbiological specifications in long shelf-life products necessitates sequential additional heat treatments of up to $125^{\circ} \mathrm{C}$ for $3-5 \mathrm{~s}$. These sequential heat treatments often employ direct steam injection/infusion technologies and can cause deleterious effects to the nutritional and organoleptic properties of products, including changes in physical properties such as viscosity, colour and generation of Maillard reaction products (Van Boekel, 1998).

Mechanical separation initially focused solely on centrifugal separation of cream, but has evolved to incorporate removal of curd fines from cheese whey, clarification of cheese brine, separation of acid curd, bacteria removal and, more recently, cold separation of spores from liquid milk. The evolution from mechanical to size-based separation in the dairy industry was a gradual one, which diversified the product portfolio that could be generated from milk. Early plant designs based on dead-end and plate- and frame-filtration techniques have been replaced with separation processes which rely upon cross-flow filtration of a liquid through a semi-permeable membrane. Membrane filtration has become the workhorse of the dairy industry for the physical separation and selective concentration of milk components. In their current form, membrane filtration processes are applied within dairy processes for removal of bacteria and spores, de-fatting of milk and whey (microfiltration), standardisation of whole/ skim milk, protein enrichment and isolation (ultrafiltration), demineralisation, concentration of total dry matter (DM) and recovery of white water streams (nano-filtration and reverse osmosis). Filtration systems are now widespread in the dairy industry and drive creation of dairy ingredients with tailored functional and nutritional properties.

Commercially, dairy products are concentrated using fallingfilm evaporators, with earlier designs incorporating thermal vapour recompression, which are now mostly superseded by more efficient mechanical vapour recompression-based systems. Both systems exploit the indirect heating of a thin film of product under vacuum, removing up to $90 \%$ of the water. 
However, evaporation is an energy-intensive process, limited by product characteristics including viscosity and stability of heat-labile components (Hasanoğlu \& Gül, 2016). To reduce energy consumption and/or maximise plant capacity relative to capital costs and plant footprint, dairy products are now often pre-concentrated using reverse osmosis and nano-filtration followed by evaporation to reach DM contents suitable for efficient stabilisation through spray-drying (Ramirez et al., 2006). Spray-drying is by far the most frequently used technology for the manufacture of dairy powders. As the last major unit operation in the powder manufacturing process, it can have far-reaching effects on both the microbial and physical quality of products.

In general, hygienic design principles are well observed and safeguarded against the risk of contamination. The fundamentals of hygienic dryer design are reviewed by Masters \& Masters (2006). However, in industry there is a continuous focus on improving hygienic design, driven largely by the European Hygienic Engineering and Design Group (EHEDG, 2018). A strong focus is placed on the integrity of drying surfaces to eliminate cracks or crevices in which microbes can proliferate, which is achieved through highquality fabrication and installation procedures, along with rigorous preventative maintenance. Clean-in-place (CIP) systems should be designed to ensure that product contact surfaces can be reached by cleaning reagents and allow for efficient post-CIP drainage and moisture elimination. This includes exhaust systems, with design of ever-more efficient and cleanable powder recovery systems (e.g. cyclones and bag filters) continuing on an ongoing basis (Masters, 2004; Cornall, 2020).

While product microbial quality is of paramount importance, many products are sold based on their physical functionality, for example, wettability and flowability. Here, the effect of preprocessing can be as important as the dryer configuration and the body of work investigating the interaction between wetprocessing and drying is continually growing (Murphy et al., 2011, 2013, 2014, 2015; McCarthy et al., 2013; Finnegan, 2021). A key feature of any spray-drying installation is the technology used for atomisation. Recently, high-pressure nozzles are more commonly used in new installations and can impart greater control over resultant powder properties such as span of particles and agglomeration (O'Sullivan et al., 2019), both of which are factors influencing key selling points such as wettability and flowability. However, due to the high operational cost of spray-drying, the main challenge lies in producing high-quality products while also maximising capacity. A commonly applied approach is to maximise water removal by pre-drying concentration steps (e.g. membrane filtration and vacuum evaporation) (Fox et al., 2010) which can be complemented by applying novel technologies to reduce the extent of viscosity development (Murphy et al.,
2013, 2015; Tanguy et al., 2015). A detailed discussion on the interaction between energy optimisation and product physical quality was presented by Patil et al. (2021).

\section{Nutritional security, sustainability and socioeconomic perspectives}

The value of dairy exports in 2020 was $€ 5.2$ billion, increasing $3 \%$ on 2019 , and the second year in a row in which dairy exports were greater than $€ 5$ billion. This was due to strong sales of butter, specialised nutritional and ingredient powders and cheese (Bord Bia, 2020). While still highly dependent on commodity production, over time, the dairy products portfolio in Ireland has evolved driven in part by demand from consumers for healthy and functional foods. The current diversity of products manufactured by the dairy industry in Ireland is shown in Figure 3.

Milk and dairy products are highly nutritious but perishable. Early shelf-life extension solutions were based on fermentation leading to soured milk and coagulated products like cheese and yoghurt. In Ireland, hard cheeses like Cheddar are most common; however, recent diversification into stretch curd cheeses like mozzarella has occurred due to market growth in particular in Asia and new market regulations. By contrast, large-scale yoghurt production has transferred abroad to super-factories, while small-to-medium-size production remains in the more specialised, including organic, sectors. However, global demand for commodities has remained strong, and the recovery of protein from milk and whey using membranes is now applied widely to milk separations. The range of protein ingredients that are currently produced in Ireland is shown in Figure 3.

The development of global economies and the requirement for nutritionally validated foods have come to the fore. The demand for ingredients with scientifically (clinically) proven health benefits aligns with the emergence of markets for functional foods. This has led to advancement in formulation for value-added ingredients that can be incorporated into foods and beverages to improve their technological and nutritional properties.

While research, and farm and processing plant management have accomplished very significant advances in milk and dairy product quality, some overarching emerging challenges include product substitution and sustainability. The industry is already being challenged by plant-based milk substitutes and this trend could potentially increase as consumers may consider such products more sustainable and better for health. Developments in fermentation technology-produced milks are progressing rapidly, and milks or milk components made using this process could potentially be used in some ingredient applications, as they may be considered more cost effective and sustainable than conventional milk. Thus, clear messages to key stakeholders are important regarding the 
WHEY PRODUCTS

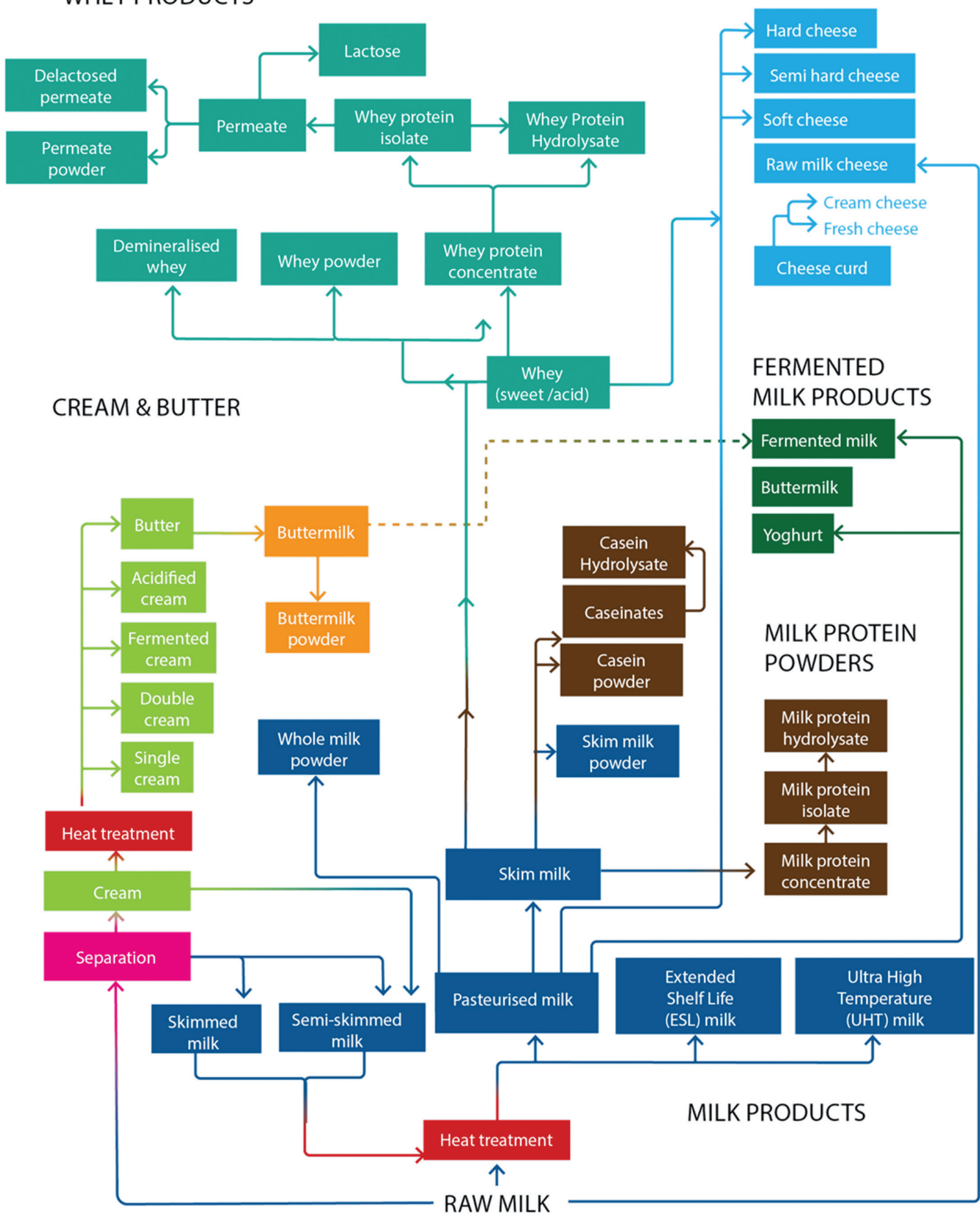

Figure 3. "Milk Map" of Ireland's Dairy Products (Adapted from the International Dairy Federation [IDF] milk tree: https://fil-idf.org/our-work/ dairy-science-and-technology/the-milk-tree-technology-and-use/.). 
benefits of dairy from nutritional security, sustainability and socioeconomic perspectives.

\section{Key pillars for the future}

\section{Evolution in analytical instrumentation}

Fatty acids in milk directly impact milk quality in terms of nutrition, sensory and functional aspects and also have the potential to influence any derived dairy product in the same way. The FA composition of milk and dairy products is influenced by many factors, including breed, stage of lactation, diet and the health of the cow. Over 400 different FAs are known to exist in milk fat, varying in relation to carbon chain length, degree of unsaturation, chain branching, geometric and positional configuration and functional groups. However, most are present at trace levels, with only 15 FAs making up $1 \%$ or greater of the total amount (Mansson, 2008). The method of choice for FA quantification is gas chromatography flame ionisation detection (GCFID), where FAs are first isolated and then derivatitised to make them volatile and suitable for GCFID analysis. Separation is mainly achieved by the different FA affinities to a non-polar column stationary phase and through the application of heat, where FAs move from the stationary phase into the mobile or carrier gas phase and into the detector. Gas chromatography flame ionisation detection are reliable instruments, even though they require some expertise to operate, and their relatively low cost in comparison to gas chromatography mass spectrometers (GCMS) makes them ideally suited for routine quantification of FA. However, onedimensional GC analysis of FA is limited, as many FA isomers exist which are both structurally and molecularly similar and thus, very difficult to separate in a single chromatographic run. To date, most analysis focuses on quantifying the most abundant FA, or at least those from C4:0 to 22:0 (O'Callaghan et al., 2016b). In order to achieve sufficient separation of these FAs, long columns are required which also results in long run times, which significantly impacts the efficiency of the method. A main approach to circumvent this is twodimensional chromatography or $\mathrm{GC} \times \mathrm{GC}$, where all or part of the eluent from the first column is passed to a second column of different polarity to enhance resolution of co-eluting FA. Two-dimensional chromatography is rapidly becoming a mainstream method to analyse semi-volatile and volatile components, as recent significant advances in hardware and software have made it more practical, easier to use and cost effective. A recent study managed to identify 51 individual FA (24 saturated, 13 monounsaturated and 14 polyunsaturated) in buffalo milk (Pegolo et al., 2017). The key element in GC×GC is the ability to modulate the flow of eluent between the two columns; traditionally, this was achieved using temperature modulation, but advances in flow modulation controlled directly by the GC software/hardware make it easier to use and control, while also negating the use of cryogenics. The utilisation of $\mathrm{GC} \times \mathrm{GC}$ with $\mathrm{MS}$ further increases resolving power in tandem with sensitivity. GC×GC, in combination with time-of-flight MS or Orbitrap MS, offers the potential to identify volatiles derived from different feeding regimes that influence aromatic qualities of milk and dairy products that previously would not have been possible.

\section{Process, products and functionality}

Advances in data analytics, including chemometrics, have led to the development of predictive algorithms, generated through mid-infrared/near-infrared (MIR/NIR) spectroscopy data that can feed information into different stages of the dairy process. The emergence of process analytical testing (PAT) via sensors and their integration, data capture and increased connectivity through the industrial internet of things (IIOT) has fuelled artificial intelligence, facilitating quality by design and processes that can adapt remotely. Moreover, recent dairy manufacturing innovations are reliant on validated milk composition and functionality datasets to optimise processing parameter settings at different stages of the process, such as concentration, heating and dehydration. As discussed above, new scientific studies in this area include using MIR/NIR spectral data for analysis of milk components and functionality, animal health and nutritional traits.

Many of the most recent ingredients illustrated in Figure 3 are produced using some form of filtration. A relatively new technology, membrane filtration is now used widely in the dairy industry to physically separate and selectively concentrate milk components (IDF fact sheet, 2020). The ratio between nutrients can be altered to obtain a liquid or powdered ingredient with specific composition and functionality, suitable for use in the lifestyle beverages already mentioned. Some processors within Ireland use microfiltration as an initial step during manufacture, for the removal of bacteria and bacterial spores and meet composition specifications. Microfiltration can be used for de-fatting of milk and whey, protein enrichment and isolation, partial demineralisation, DM concentration and water recovery. The majority of milk protein-based ingredients shown in Figure 3 are selectively concentrated using ultrafiltration or microfiltration membranes; however, a more recent development is the production of micellar casein and corresponding serum proteins. Using microfiltration (with pore sizes of about $0.1-0.2 \mu \mathrm{m}$ ), it is possible to retain the casein fraction (in the retentate) and allow the serum proteins (65-95\%) to pass through the membrane into the permeate stream, depending on the parameters used. The retentate is an MCC or isolate micellar casein $(\mathrm{MCl})$, depending on the extent of processing (Figure 3). While MCC and $\mathrm{MCl}$ ingredients are not currently produced in Ireland, the technology is available in some processing plants. Further 
alteration of the functionality of protein ingredients can be achieved by pre- or post-processing treatments such as heat treatment or interaction with other ingredients, for example, specific minerals. Further fractionation is also possible using industrial chromatography, emulating what is currently being carried out in other dairy ingredient-producing countries. Finally, Irish dairy processors use enzymatic hydrolysis of proteins to improve functionality, reduce allergenicity and release targeted peptides. This has generated a new category of ingredients that require additional quality control to ensure that bioactivity in selected protein fractions and peptides is retained during processing.

Expansion in the number of dairy product streams has meant additional testing regimes, with advanced testing methodologies, for milk processors, in order to confirm quality specifications. Much research has been conducted over previous years, in Ireland, directed at milk quality and safety within the supply chain serving a global marketplace. Studies have included physical (e.g. functionality) and nutritional (bioactivity) parameters, as well as bacteriological parameters. Ireland's dairy sector continues to attain the highest standards for quality and safety, and is recognised for its excellence in milk and dairy product quality.

\section{Digitalisation}

Innovation in digitalisation is particularly important in this sector due to the level of international trade, health and safety and regulatory issues. Modest steps in digitisation have the potential to improve production and processing efficiency, quality, safety and traceability of dairy products. However, implementation is highly dependent on regulations and local infrastructure, including basic internet access. Connectivity is key, both in terms of allowing access to information and enabling capacity to share digital platforms and applications directly related to dairy topics/challenges; an example may include block chain technology, which requires increased interconnectivity between individual units within a supply chain and the associated financial and regulatory supporting services.

Examples of data management approaches within individual platforms may include the following: (a) effect of level of nutrition (grass intake) on milk protein (incorporating herd management and milk composition datasets); (b) effects of plate cooling on milk cooling costs at farm level; (c) effect of temperature and duration of milk storage on the microbial quality of milk in the silo at milk assembly stage; and (d) effect of curd cutting time in the vat on cheese yield at the processing plant stage. A further level of data management is the integration of data on these four platforms; this would involve using data generated on one platform to predict measured outcomes at a further platform, thus enabling changes in practice and potential improvement, thus benefitting from "real-time" data to manage outcomes. An example may include the effect of milk protein level on cheese yield or the effect of milk SCC on cheese quality.

Evidence-based information could potentially be used to add value; examples may include evidence of milk originating from pasture grazing cows or evidence that could be used to justify payments for various grades of product, depending on composition of the raw material. A number of dairy farmers are already using digital technologies such as electronic milk meters to precisely measure milk production, pedometers to detect the increased numbers of steps linked to cows in heat and analyses of milk conductivity to detect mastitis. Internet of things (IOT) sensors with applications in milk quality are now also commercially available. They include wireless and portable NIR devices and handheld scanners that measure protein, fat, lactose and total solids and temperature. These microsensors use micro-electro-mechanical systems (MEMS) technology and can operate at wavelengths between 1,350 and 2,450 nm. However, studies are required to validate their use against current routine testing approaches. IoT sensors for temperature measurements are also commercially available. These infrared (IR) sensors are available for installation in milk bulk tanks and can monitor and store milk storage temperatures. Specifically, these systems can release an alert to farmers if temperatures are not maintained or begin to increase. All data are stored on a local system which can be connected to a tablet or phone device, where personalised data can be viewed via simple dashboards. The system can also send out alerts to a farmer in the event of temperature spikes. This approach may be more or less relevant to particular farms, depending on the farmer's disposition towards new technologies, the labour efficiency on the farm and the investment capabilities of the farm. However, it is crucially important in all cases, that the farmer has sufficient support from independent consultants or advisers, in the form of clear information on how to use the additional data available on-farm to best advantage.

Potential datasets that may be used by milk purchasers within the milk assembly platform include milk volume in different farm bulk tanks to allow efficient logistics for collection of milk; milk volume supplied by different farms; milk SCC and TBC supplied by different farms, as well as temperature and time duration in each tanker and in each silo.

With edge and cloud analytics, dashboards can be developed and shared between farmers and dairy processors for viewing milk quality parameters. There is also potential to develop suitable, accurate and user-friendly prediction models for farmers. The application of temperature sensor loT systems allows full transparency in the storage conditions of the milk between the farmer and processor, which can be important for traceability or payment system. However, some challenges do exist, which include issues pertaining to the security and 
ownership of data collected and stored in the cloud, and these need to be addressed.

\section{Conclusion}

While milk quality may be considered a dynamic standard or concept, there are some predictions that can be made with a degree of certainty. The demand for dairy products is increasing, so markets will need to be supplied, but increasingly stringent consumer-related quality standards will represent an associated challenge. Therefore, it is important to focus on an evolving framework to address these standards and markets.

Much research has been described in the foregoing paper, which has played a significant role in developing and progressing the dairy sector to its current excellent status. Some of the long-standing issues have been addressed through science and technology developments. However, some gaps in knowledge and challenges remain. Research on grass-fed milk has highlighted and characterised the unique compositional and sensory attributes of this milk and dairy products, which is particularly important to Ireland. However, the need for legislation to distinguish and protect grass-fed milk products, ideally by rapid spectral methods, is clear. The complexity of enzyme systems and their diverse and sophisticated modes of action have been investigated in depth, but significant knowledge gaps remain, and work continues on their role in influencing processing efficiency and product quality. While the risk of chlorine residues has largely been eliminated from the dairy supply chain as a consequence of the moratorium on the use of chlorine-based cleaning agents, it is absolutely critical that microbial hygiene and quality is not compromised. In addition, there is an ongoing need for vigilance regarding the emergence of other potential residues from the use of replacement or other products.

Some key considerations for the future include new technologies, new instrumentation, standards, payment incentives and digitalisation. As quality parameters become increasingly important, detection limits within analytical methodology become vital, and likewise, as precision management of steps along the milk process line become standard practice, the development and use of new and progressive instrumentation is necessary. These instruments must be reliable and ideally not require comprehensive expertise to operate, and they should ideally be suited to routine quantification or determinations.

The International Dairy Federation (IDF) has contributed to the development of standards for the dairy sector over many years; the organisation and its members from different dairy research organisations globally (including Teagasc) participate in the development of science-based, globally harmonised standards, guidelines, codes of practice and related methodologies, to continually improve the regulatory environments of the dairy sector. These include food standards, animal health and welfare standards, standards for methods of analysis and sampling and various standards for milking machines. This is increasingly important in light of increasing international dairy trade.

Financial reward has been used successfully in the past to improve milk quality in terms of TBC and SCC. This could be complemented by putting a monetary value on more recently defined quality parameters or on achieving a suite of quality standards; however, this would need to be accompanied by fast and reliable measuring techniques. The whole area of digitalisation, data management integration of data platforms, the use of evidence-based information and real-time measures to improve predictability and control of manufacturing processes and decision-making will be crucial pillars for the dairy sector of the future. Digitalisation has potential to optimise logistical chains within the processing stages, and change the pattern of organisation from "inspect" and "reject" to "predict" and "prevent".

Even as international quality standards become more stringent, Irish milk has continued to achieve premium quality status as a direct consequence of greater scientific knowledge of the factors affecting it and the quality control measures implemented at farm and processing level, as well as training and education of farmers, improved hygiene, measurement systems, documentation and traceability. However, much still needs to be done, and whatever the future holds for consumer trends and markets, quality will be foremost.

\section{References}

Adam, L.C., Fabian, I., Suzuki, K. and Gordon, G. 1992. Hypochlorous acid decomposition in the $\mathrm{pH}$ 5-8 region. Inorganic Chemistry 31 : 3534-3541.

Alothman, M., Hogan, S.A., Hennessy, D., Dillon, P., Kilcawley, K.N., O'Donovan, M., Tobin, J., Fenelon, A.A. and O'Callaghan, T.F. 2019. The "grass-fed" milk story: understanding the impact of pasture feeding on the composition and quality of bovine milk. Foods 8: 350.

Auldist, M.J., Coats, S., Sutherland, B.J., Mayes, J.J., McDowell, G. and Rogers, G.L. 1996. Effects of somatic cell count and stage of lactation on raw milk composition and the yield and quality of Cheddar cheese. Journal of Dairy Research 63: 269-280.

Barbano, D.M., Rasmussen, R.R. and Lynch, J.M. 1991. Influence of milk somatic cell count and milk age on cheese yield. Journal of Dairy Science 74: 369-388.

Berry, D.P. 2018. Symposium review: breeding a better cow-will she be adaptable? Journal of Dairy Science 101: 3665-3685.

Berry, D.P., O’Brien, B., O'Callaghan, E.J., O'Sullivan, K.O. and Meaney, W.J. 2006. Temporal trends in bulk tank somatic cell 
count and total bacterial count in Irish dairy herds during the past decade. Journal of Dairy Science 89: 4083-4093.

Berry, D.P., Dunne, F.L., McHugh, N., McParland, S., O'Brien, A.C. and Twomey, A.J. 2022. The development of effective ruminant breeding programmes in Ireland from science to practice. Irish Journal of Agricultural and Food Research 61: (in press).

Bord Bia Sectoral Analysis - Export Performance and Prospects 2020/21. https://www.bordbia.ie/globalassets/bordbia2020/industry/ insights/performance-prospects/bord-bias-export-performanceprospects-2020-2021-report.pdf. Accessed 07/12/2021.

Capuano, E., Rademaker, J., van den Bijgaart, H.M. and van Ruth, S. 2014a. Verification of fresh grass feeding, pasture grazing and organic farming by FTIR spectroscopy analysis of bovine milk. Food Research International 60: 59-65.

Capuano, E., van der Veer, G., Boerrigter-Eenling, R., Elgersma, A., Rademaker, J., Sterian, A. and van Ruth, S.M. 2014b. Verification of fresh grass feeding, pasture grazing and organic farming by cows farm milk fatty acid profile. Food Chemistry 164: 234-241.

Cheng, Z., O'Sullivan, M.G., Kerry, J.P., Drake, M.A., Miao, S., Kaibo, D. and Kilcawley, K.N. 2020. A cross-cultural sensory analysis of skim milk powdered milk produced from pasture and non-pasture diets. Food Research International 138: Part a, December 2020.

Clarke, H.J., Griffin, C., Rai, D.K., O'Callaghan, T.F., O'Sullivan, M.G., Kerry, J.P and Kilcawley, K.N. 2019. Dietary compounds influencing the sensorial, volatile and phytochemical properties of bovine milk. Molecules 25: 26.

Cornall, J. 2020. GEA redesigns SANICIP bag filter for spray dryers. https://www.dairyreporter.com/Article/2020/09/03/GEA-redesignsSANICIP-bag-filter-for-spray-dryers. Accessed 07/12/2021.

Couvreur, S., Hurtaud, C., Lopez, C., Delaby, L. and Peyraud, J.L. 2006. The linear relationship between the proportion of fresh grass in the cow diet, milk fatty acid composition, and butter properties. Journal of Dairy Science 89: 1956-1969.

DeMarchi, M., Toffanin, V., Cassandro, M. and Penasa, M. 2014. Invited review: mid-infrared spectroscopy as a phenotyping tool for milk traits. Journal of Dairy Science 97: 1171-1186.

Dillon, P., Hennessey, T., Shalloo, L., Thorne, F. and Horan, B. 2008. Future outlook for the Irish dairy industry: a study of international competitiveness, influence of international trade reform and requirement for change. International Journal of Dairy Technology 61: 16-29.

Downey, L. and Doyle, P.T. 2007. Cow nutrition and dairy product manufacture - implications of seasonal pasture-based milk production systems. Australian Journal of Dairy Technology 62: 3-11.

EC. 2005. COMMISSION REGULATION (EU) 2020/749 of 4 June 2020, amending Annex III to Regulation (EC) No 396/2005 of the European Parliament and of the Council. Official Journal of the European Union L 178/7.

EHEDG. 2018. "EHEDG Guidelines", 2nd Edition. Available online: https://www.ehedg.org/ [Accessed 28 May 2021].
Faulkner, H., O'Callaghan, T.F., McAuliffe, S., Hennessy, D., Stanton, C., O'Sullivan, M.G., Kerry, J.P and Kilcawley, K.N. 2018. Effect of different forage types on the voaltile and sensory properties of bovine milk. Journal of Dairy Science 101: 1034-1047.

Finnegan, E.W., Mahomud, S., Murphy, E.G. and O'Mahony, J.A. 2021. The influence of pre-heat treatment of skim milk on key quality attributes of fat filled milk powder made therefrom. International Journal of Dairy Technology 74: 404-413.

Fox, P.F. and Kelly, A.L. 2006a. Indigenous enzymes in milk: overview and historical aspects - Part 1. International Dairy Journal 16: 500-516.

Fox, P.F. and Kelly, A.L. 2006b. Indigenous enzymes in milk: overview and historical aspects - Part 2. International Dairy Journal 16: 517-532.

Fox, P.F., O'Flaherty, F. and Kelly, A.L. 2006. Indigenous proteolytic enzymes in milk: a brief overview of the present state of knowledge. International Dairy Journal 16: 563-572.

Fox, M., Akkerman, C., Straatsma, H. and de Jong, P. 2010. Energy reduction by high dry matter concentration and drying. New Food 2: 60-63.

France, T., Kelly, A.L., Crowley, S.V. and O'Mahony, J.A. 2021. The effects of temperature and transmembrane pressure on protein, calcium and plasmin partitioning during microfiltration of skim milk. International Dairy Journal 114: article number 104930.

Frizzarin, M., Gormley, I.C., Berry, D.P., Murphy, T.B., Casa, A., Lynch, A. and McParland, S. 2021. Predicting cow milk quality traits from routinely available milk spectra using statistical machine learning methods. Journal of Dairy Science 104: 7438-7447.

FSAI. 2015. Food Safety Authority of Ireland. Toxicology Factsheet, Series Issue no. 2, November 2015.

Garvey, E.C., Sander, T., O'Callaghan, T.F., Drake, M., Fox, S., O'Sullivan, M.G., Kerry, J.P. and Kilcawley, K.N. 2020. A crosscultural evaluation of liking and perception of salted butter produced from different feed systems. Foods 9: 1767.

Gazi, I., Vilalva, I.C. and Huppertz, T. 2014. Plasmin activity and proteolysis in milk protein ingredients. International Dairy Journal 38: 208-212.

Geary, U., Lopez-Villalobos, N., Begley, N., McCoy, F., O’Brien, B., O'Grady, L. and Shalloo, L. 2012. Estimating the effect of mastitis on the profitability of Irish dairy farms. Journal of Dairy Science 95: 3662-3673.

Geary, U., Lopez-Villalobos, N., O’Brien, B., Garrick, D.J. and Shalloo, L. 2013a. Meta-analysis to investigate relationships between somatic cell count and raw milk composition, Cheddar cheese processing characteristics and cheese composition. Irish Journal of Agricultural and Food Research 52: 119-133.

Geary, U., Lopez-Villalobos, N., O'Brien, B., Garrick, D.J. and Shalloo, L. 2013b. Examining the impact of mastitis on the profitability of the Irish dairy industry. Irish Journal of Agricultural and Food Research 52: 135-149. 
Gleeson, D. 2018. Moorepark Dairy Levy Research Update Series 37. Available online: https://www.teagasc.ie/media/website/animals/ dairy/research-farms/Non-chlorine-cleaning-protocol-april-18.pdf. Accessed 07/12/2021.

Gleeson, D. and O'Brien, B. 2016. Minimizing chlorate levels in the dairy chain. Irish Farm Business Dairying 3: 20-22.

Gleeson, D., O'Brien, B. and Jordan, K.N. 2013. The effect of using non-chlorine products for cleaning and sanitising milking equipment on bacterial numbers and residues in milk International Journal of Dairy Technology 66: 182.

Gómez-Mascaraque, L.G., Kilcawley, K., Hennessy, D., Tobin, J.T. and O'Callaghan, T.F. 2020. Raman spectroscopy: a rapid method to assess the effects of pasture feeding on the nutritional quality of butter. Journal of Dairy Science 103: 8721-8731.

Guinee, T.P. and O'Brien, B. 2010. The quality of milk for cheese manufacture. In: "Technology of Cheesemaking", 2nd Edition (eds. B.A. Law and A. Tamime), John Wiley \& Sons Ltd, Great Britain, pages 1-67. ISSN 978140518298022654.

Guinee, T.P., O'Brien, B. and Mulholland, E. 2007. The suitability of milk from a spring calved dairy herd during the transition from normal to very late lactation for the manufacture of low-moisture Mozzarella cheese. International Dairy Journal 17: 133-142.

Hasanoğlu, A. and Gül, K. 2016. Concentration of skim milk and dairy products by forward osmosis. Journal of the Turkish Chemical Society, Section B: Chem. Eng. 1: 149-160.

Huijps, K., Lam, T.J.G.M. and Hogeveen, H. 2008. Costs of mastitis: facts and perception. Journal of Dairy Research 75: 113-120.

IDF. 2020. IDF Factsheet 009/ 2019: Manufacture of milk protein concentrates and isolates by membrane filtration. https://fil-idf.org/ product-category/fact-sheets/. Accessed 07/12/2021.

Kalač, P. 2011. The effects of silage feeding on some sensory and health attributes of cow's milk: a review. Food Chemistry 125: 307-317.

Kelly, A.L. and Larsen, K.B. eds. 2021. "Agents of change: enzymes in milk and dairy products". Springer-Nature, New York.

Kelly, M., Kolver, E., Bauman, D., van Amburgh, M. and Muller, L. 1998. Effect of intake of pasture on concentrations of conjugated linoleic acid in milk of lactating cows. Journal of Dairy Science 81: 1630-1636.

Kelly, P.T, O'Sullivan, K., Berry, D.P., More, S.J., Meaney, W.J., O'Callaghan, E.J. and O'Brien, B. 2009. Farm management factors associated with bulk tank somatic cell count in Irish dairy herds. Irish Veterinary Journal 62(Suppl 4): S45-S51.

Kelly, P., Shalloo, L., Wallace, M. and Dillon, P. 2020. The Irish dairy industry - recent history and strategy, current state and future challenges. International Journal of Dairy Technology 70: 1-15.

Kilcawley, K., Faulkner, H., Clarke, H., O'Sullivan, M. and Kerry, J. 2018. Factors influencing the flavour of bovine milk and cheese from grass based versus non-grass based milk production systems. Foods 7: 37.

Li, B.Z., Waldron, D.S., Tobin, J.T., Subhir, S., Kelly, A.L. and McSweeney, P.L.H. 2020. Evaluation of production of Cheddar cheese from micellar casein concentrate. International Dairy Journal 106: article number 104711.

Lin, Y., O'Mahony, J.A., Kelly, A.L. and Guinee, T.P. 2017. Seasonal variation in the composition and processing characteristics of herd milk with varying proportions of milk from spring-calving and autumn-calving cows. Journal of Dairy Research 84: 444-452.

Machado, S.G., Bagliniere, F., Marchand, S., Van Coillie, E., Vanetti, M.C.D., De Block, J. and Heyndrickx, M. 2017. The biodiversity of the microbiota producing heat-resistant enzymes responsible for spoilage in processed bovine milk and dairy products. Frontiers in Microbiology 8: article number 302.

Magan, J.B., O'Callaghan, T.F., Zheng, J., Zhang, L., Mandal, R., Hennessy, D., Fenelon, M.A., Wishart, D.S., Kelly, A.L. and McCarthy, N.A. 2019. Impact of bovine diet on metabolomic profile of skim milk and whey protein ingredients. Metabolites 9: 305.

Magan, J.B., O'Callaghan, T.F., Zheng, J., Zhang, L., Mandal, R., Hennessy, D., Fenelon, M.A., Wishart, D.S., Kelly, A.L. and McCarthy, N.A. 2020. Effect of diet on the vitamin b profile of bovine milk-based protein ingredients. Foods 9: 578.

Magan, J.B., O'Callaghan, T.F., Kelly, A.L. and McCarthy, A.A. 2021. Compositional and functional properties of milk and dairy products derived from cows fed pasture or concentrate-based diets. Comprehensive Reviews in Food Science and Food Safety 20: 2769-2800.

Mansson, H.L. 2008. Fatty acids in bovine milk fat. Food and Nutrition Research 52.

Masters, K. 2004. Current market-driven spray drying development activities. Drying Technology 22: 1351-1370.

Masters, K. and Masters, S. 2006. Hygienic design requirements for spray drying operations. Drying Technology 24: 685-693.

McCarthy, N.A., Gee, V.L., Hickey, D.H., Kelly, A.L., O'Mahony, J.A. and Fenelon, M.A. 2013. Effect of protein content on the physical stability and microstructure of a model infant formula. International Dairy Journal 29: 53-59.

McCarthy, W.P., O'Callaghan, T.F., Danahar, M., Gleeson, D., O'Connor, C., Fenelon, M.A. and Tobin, J.T. 2018. Chlorate and other oxychlorine contaminants within the dairy supply chain. Comprehensive Reviews in Food Science and Food Safety 17: 1561-1575.

McDermott, A., Visentin, G., McParland, S., Berry, D.P., Fenelon, M.A. and De Marchi, M. 2016. Effectiveness of mid-infrared spectroscopy to predict the color of bovine milk and the relationship between milk color and traditional milk quality traits. Journal of Dairy Science 99: 3267-3273.

McHugh, A.J., Feehily, C., Fenelon M.A., Gleeson, D., Hill C. and Cotter P.D. 2020. Tracking the dairy microbiota from farm bulk tank to skimmed milk powder. mSystemes 5: e00226-20.

McParland, S. and Berry, D.P. 2016. The potential of Fourier transform infrared spectroscopy of milk samples to predict energy intake and efficiency in dairy cows. Journal of Dairy Science 99: 4056-4070.

Mee, J.F., Barrett, D., Silva Boloña, P., Conneely, M., Earley, B., Fagan, S., Keane, O.M. and Lane, E.A. 2022. Ruminant health research - progress to date and future prospects, with an 
emphasis on Irish research. Irish Journal of Agricultural and Food Research (in press).

More, S.J., McKenzie, K., O'Flaherty, J., Doherty, M.L., Cromie, A.R. and Magan, M.J. 2010. Setting priorities for non-regulatory animal health in Ireland: results from an expert Policy Delphi study and a farmer priority identification survey. Preventative Veterinary Medicine 95: 198-207.

Moscovici Joubran, A., Pierce, K.M., Garvey, N., Shalloo, L. and O'Callaghan, T.F. 2021. Invited review: a 2020 perspective on pasture-based dairy systems and products. Journal of Dairy Science 104: 7364-7382.

Murphy, E.G., Tobin, J.T., Roos, Y.H. and Fenelon, M.H. 2011. The effect of high velocity steam injection on the colloidal stability of concentrated emulsions for the manufacture of infant formulations. Procedia Food Science 1: 1309-1315.

Murphy, E.G., Tobin, J.T., Roos, Y.H. and Fenelon, M.H. 2013. A highsolids steam injection process for the manufacture of powdered infant milk formula. Dairy Science and Technology 93: 463-475.

Murphy, E.G., Fenelon, M.H., Roos, Y.H. and Hogan, S.A. 2014. Decoupling macronutrient interactions during heating of model infant milk formulas. Journal of Agricultural and Food Chemistry 62: 10585-10593.

Murphy, E.G., Roos, Y.H., Hogan, S.A., Maher, P.G., Flynn, C.G. and Fenelon, M.A. 2015. Physical stability of infant milk formula made with selectively hydrolysed whey proteins. International Dairy Journal 40: 39-46.

Nieminski, E.C., Chaudhuri, S. and Lamoreaux, T. 1993. The occurrence of DBPs in Utah drinking waters. Journal-American Water Works Association 85: 98-105.

O'Brien, B. 2009. Teagasc, Milk Quality Handbook 81. Moorepark Dairy Levy Research Update No. 8, Practical Steps to Improve Milk Quality, Milk Quality Handbook, Teagasc, 2008.

O'Brien, B., Guinee, T.P., Kelly, A. and Joyce, P. 2006. Processability of late lactation milk from a spring calved dairy herd. Australian Journal of Dairy Technology 61: 3-7.

O'Callaghan, T.F., Hennessy, D., McAuliffe, S., Kilcawley, K.N., O'Donovan, M., Dillon, P., Ross, R.P. and Stanton, C. 2016a. Effect of pasture versus indoor feeding systems on raw milk composition and quality over an entire lactation. Journal of Dairy Science 99: 9424-9440.

O'Callaghan, T.F., Faulkner, H., McAuliffe, S., O'Sullivan, M.G., Hennessy, D., Dillon, P., Kilcawley, K.N., Stanton, C. and Ross, R.P. 2016b. Quality characteristics, chemical composition, and sensory properties of butter from cows on pasture versus indoor feeding systems. Journal of Dairy Science 99: 9441-9460.

O'Callaghan, T.F., Mannion, D.T., Hennessy, d., McAuliffe, S., O'Sullivan, M.G., Leeuwendaal, N., Beresford, T.P., Dillon, P., Kilcawley, K.N., Sheehan, J.J., Ross, R.P. and Stanton, C. 2017. Effect of pasture versus indoor feeding systems on quality characteristics, nutritional composition, and sensory and volatile properties of full-fat cheddar cheese. Journal of Dairy Science 100: 6053-6073.
O’Callaghan, T.F., Vázquez-Fresno, R., Serra-Cayuela, A., Dong, E., Mandal, R., Hennessy, D., McAuliffe, S., Dillon, P., Wishart, D., Stanton, C. and Ross, R. 2018. Pasture feeding changes the bovine rumen and milk metabolome. Metabolites 8: 27.

O'Connell, A., McParland, S., Ruegg, P.L., O'Brien, B. and Gleeson, D. 2015. Seasonal trends in milk quality in Ireland between 2007 and 2011. Journal of Dairy Science 98: 3778-3790.

O'Connell, A., Kelly, A.L., Tobin, J., Ruegg, P.L. and Gleeson, D. 2016. The effect of storage conditions on the composition and functional properties of blended bulk tank. Journal of Dairy Science. 100 991-1003.

O'Sullivan, J.J., Norwood, E.-A., O'Mahony, J.A. and Kelly, A.L. 2019. Atomisation technologies used in spray drying in the dairy industry: a review. Journal of Food Engineering 243: 57-69.

Paludetti, L.F., Kelly, A.L., O'Brien, B. and Gleeson, D. 2019. Monitoring residue concentrations in milk from farm and throughout a milk powder manufacturing process. Journal of Dairy Research 86: 341-346.

Paludetti, L.F., Kelly, A.L. and Gleeson, D. 2020a. Effect of thermoresistant protease of Pseudomonas fluorescens on rennet coagulation properties and proteolysis of milk. Journal of Dairy Science 103: 4043-4045.

Paludetti, L.F., O'Callaghan, T.F., Sheehan, J.J., Gleeson, D. and Kelly, A.L. 2020b. Effect of Pseudomonas fluorescens protease on the quality of Cheddar cheese. Journal of Dairy Science 103: 7865-7878.

Panthi, R.R., Sundekilde, U.K., Kelly, A.L., Hennessy, D., Kilcawley, K.N., Mannion, D.T., Fenelon, M.A. and Sheehan, J.J. 2019. Influence of herd diet on the metabolome of maasdam cheeses. Food Research international 123: 722-731.

Parmar, P., Lopez-Villalobos, N., Tobin, T., Murphy, E., McDonagh, A., Crowley, S.V., Kelly, A.L. and Shalloo, L. 2020. The effect of compositional changes due to seasonal variation on milk density and the determination of season-based density conversion factors for use in the dairy industry. Foods 9: 1004.

Patil, M.H., Tanguy, G., Le Floch-Fouéré, C., Jeantet, R. and Murphy, E.G. 2021. Energy usage in the manufacture of dairy powders: advances in conventional processing and disruptive technologies. Drying Technology 39: 1595-1613.

Pegolo, S., Stocco, G., Mele, M., Schiavon, S., Bittante, G. and Cecchinato, A. 2017. Factors affecting variations in the detailed fatty acid profile of Mediterranean buffalo milk determined by 2-dimensional gas chromatography. Journal of Dairy Science 100: 2564-2576.

Politis, I. and Ng-Kwai-Hang, K.F. 1988a. Effects of somatic cell count and milk composition on cheese composition and cheese making efficiency. Journal of Dairy Science 71: 1711-1719.

Politis, I. and NgKwai-Hang, K.F. 1988b. Effects of somatic cell counts and milk composition on the coagulating properties of milk. Journal of Dairy Science 71: 1740-1746. 
Politis, I. and Ng-Kwai-Hang, K.F. 1988c. Association between somatic cell count of milk and cheese-yielding capacity. Journal of Dairy Science 71: 1720-1727.

Quigley, L., O'Sullivan, O., Beresford, T.P., Ross, R.P. Fitzgerald, G.F. and Cotter, P. 2012 High-throughput sequencing for detection of subpopulations of bacteria not previously associated with artisanal cheeses. Applied and Environmental Microbiology 78: 5717-5723.

Quigley, L, McCarthy, R., O'Sullivan, O., Beresford, T.P., Fitzgerald, G.F., Ross, R.P., Stanton, C and Cotter, P.D. 2013. The microbial content of raw and pasteurize cow milk as determined by molecular approaches. Journal of Dairy Science 96: 4928-4937.

Quigley, L., O'Sullivan, D.J., Daly, D., O'Sullivan, O., Burdikova, Z., Vana, R., Beresford, T.P., Ross, R.P., Fitzgerald, G.F., McSweeney, P.L.H., Giblin, L., Sheehan, J.J., Cotter, P.D. 2016. Thermus and the pink discoloration defect in cheese. mSystems 1: e00023-16.

Ramirez, C., Patel, M. and Blok, K. 2006. From fluid milk to milk powder: energy use and energy efficiency in the European dairy industry. Energy 31: 1984-2004.

Reich, C., Wenning, M., Dettling, A., Luma, K.E., Scherer, S. and Hinrichs, J. 2017. Thermal resistance of vegetative thermophilic spore forming bacilli in skim milk isolated from dairy environments. Food Control 82: 114-120.

Ring, S., Evans, R.D., Cromie, A.R. and Berry, D.P. 2021. Crosssectional analyses of a national database to determine if superior genetic merit translates to superior dairy cow performance. Journal of Dairy Science 104: 8076-8093.

Ryan, S, Gleeson, D, Jordan, K, Furey, A., O'Sullivan, K. and O'Brien, B. 2013. Strategy for the reduction of trichloromethane residue levels in farm bulk milk. Journal of Dairy Research $\mathbf{8 0}$ : 184-189.

Scarso, S. McParland, S., Visentin, G., Berry, D.P. McDermott, A. and De Marchi, M. 2017. Genetic and nongenetic factors associated with milk color in dairy cows. Journal of Dairy Science 100: 7345-7361.

Snyder, S.A., Stanford, B.D., Pisarenko, A.N., Gordon, G. and Asami, M. 2009. "Hypochlorite - An assessment of factors that influence the formation of perchlorate and other contaminants". American Water Works Association, Denver, Colorado.

Soyeurt, H., Dehareng, F., Gengler, N., McParland, S., Wall, E., Berry, D.P., Coffey, M. and Dardenne, P. 2009. Mid-infrared prediction of bovine milk fatty acids across multiple breeds, production systems, and countries. Journal of Dairy Science 94: 1657-1667.

Tanguy, G., Dolivet, A., Garnier-Lambrouin, F., Méjean, S., Coffey, D., Birks, T. and Jeantet, R. 2015. Concentration of dairy products using a thin film spinning cone evaporator. Journal of Food Engineering 166: 356-363.

Tiefel, P. and Guthy, K. 1997. Model tests for the formation of TCM by chlorine containing cleaning and disinfection products. Milchwissenschaft 52: 686-691.

Timlin, M., Tobin, J.T., Brodkorb, A., Murphy, E.G., Dillon, P., Hennessy, D., O'Donovan, M., Pierce, K.M. and O'Callaghan, T.F. 2021. The impact of seasonality in pasture-based production systems on milk composition and functionality. Foods 10: 607.

Van Boekel, M.A.J.S. 1998. Effect of heating on Maillard reactions in milk. Food Chemistry 62: 403-414.

Visentin, G., McParland, S., De Marchi, M., McDermott, A., Fenelon, M.A., Penasa, M. and Berry, D.P. 2017. Processing characteristics of dairy cow milk are moderately heritable Journal of Dairy Science 100: 6343-6355.

Walshe, M.J. 1968. The growth and future development of the dairy industry in the Republic of Ireland. Journal of the Society of Dairy Technology 21: 190-198.

World Health Organisation (WHO). 2005. Chlorite and chlorate in drinking-water. Background document for development of WHO guidelines for drinking-water quality. Available online: WHO/SDE/ WSH/05.08/86. Accessed 07/12/2021.

Yap, M. and Cotter, P. 2020. Understanding the impact of chlorine/ chlorine-free cleaning approaches and other factors on the microbial composition of raw milk. Presented at Teagasc Moorepark Milk Quality Workshop, December, 2020. Available online: https:// www.teagasc.ie/media/website/animals/dairy/MinYap--Impact_of_ cleaning_and_other_factors_on_microbial_composition.pdf.

Zhang, C.Y., Bijl, E. and Hettinga, K. 2018. Destabilisation of UHT milk by protease AprX from Pseudomonas and plasmin. Food Chemistry 263: 127-134.

Zhang, C.Y., Bijl, E., Svensson, B. and Hettinga, K. 2019. The extracellular protease AprX from Pseudomonas and its spoilage potential for UHT milk: a review. Comprehensive Reviews in Food Science and Food Safety 18: 834-852. 